\title{
ANATOMICAL AND FUNCTIONAL OUTCOMES OF FEMINIZING GENITOPLASTY FOR AMBIGUOUS GENITALIA IN PATIENTS WITH VIRILIZING CONGENITAL ADRENAL HYPERPLASIA
}

\author{
Maria Helena Palma Sircili, Berenice B. de Mendonca, Francisco Tibor Denes, \\ Guiomar Madureira, Tânia Aparecida Sartori Sanchez Bachega, and Frederico \\ Arnaldo de Queiroz e Silva
}

\begin{abstract}
Sircili MHP, Mendonça BB de, Denes FT, Madureira G, Bachega TASS, Queiroz e Silva FA de. Anatomical and functional outcomes of feminizing genitoplasty for ambiguous genitalia in patients with virilizing congenital adrenal hyperplasia. Clinics. 2006;61(3):209-14.
\end{abstract}

The ideal surgical technique and appropriate age for performing feminizing genitoplasty are debatable, and few long-term outcome studies have been reported.

PURPOSE: To report a retrospective study on anatomical and functional outcomes of feminizing genitoplasty in patients with virilizing congenital adrenal hyperplasia.

METHODS: We selected 34 patients (mean age $=3.4 \pm 2.5 \mathrm{yr}$ ) with genital ambiguity classified according to Prader stage. Follow-up ranged from 2 to 16 years. Clitoral length ranged from 1.9 to $5.0 \mathrm{~cm} ; 28$ patients had a single perineal orifice, and 6 had a double orifice. The surgical technique included clitorovaginoplasty in a single procedure and was carried out before 2 years of age in 18 patients. Clitoroplasty was performed with glans preservation in all patients. Blood supply was exclusively maintained by the frenular pedicle in $97 \%$ of the cases, whereas clitoral dorsal nerves and vessels were preserved in the remaining $3 \%$. The opening of the urogenital sinus was performed using either the Y-V perineal flap procedure (25 patients) or the cut-back incision procedure (8 patients).

RESULTS: Good morphological and functional results were achieved in $68 \%$ of the patients; $21 \%$ of the patients had surgical complications, such as incision bleeding ( 2 cases), glans necrosis ( 1 girl with Prader V), and vaginal introitus stenosis (4 cases). Three of the latter underwent dilation with acrylic molds in the post-pubertal period with good functional results.

CONCLUSIONS: We conclude that single-stage feminizing genitoplasty consisting of vulvoplasty, clitoroplasty, and Y-V perineal flap produced good cosmetic and functional results in virilized girls with congenital adrenal hyperplasia, with few complications. In addition, this surgical approach prevented the need for neovaginaplasty even in patients with high vaginal insertion.

KEYWORDS: Ambiguous genitalia. Feminizing genitoplasty. Congenital adrenal hyperplasia. Anatomical and functional outcomes.

\section{INTRODUCTION}

Ambiguous genitalia are a major challenge to physicians and surgeons. ${ }^{1}$ Virilizing congenital adrenal hyper-

Endocrinology Unit, Hospital das Clínicas, São Paulo University Medical School - São Paulo/SP, Brazil.

Urology Department, Hospital das Clínicas, São Paulo University Medical School - São Paulo/SP, Brazil.

Email: mhps_msm@yahoo.com

Received for publication on February 07, 2006.

Accepted for publication on February 23, 2006. plasia due to 21-hydroxylase deficiency is the most common cause of female pseudohermaphroditism. As a result of this enzymatic deficiency, cortisol secretion decreases with a compensatory increase in ACTH output, which in turn stimulates the production of cortisol precursors and adrenal androgens. ${ }^{2}$ The high levels of androgens result in several degrees of virilization of external genitalia; the internal genitalia have normal development. Surgical correction aims at creating morphologically and functionally normal external genitalia.

Few studies have reported the long-term results of 
feminizing genitoplasty. ${ }^{3-5}$ Our objective was to evaluate, in a retrospective study, the anatomical and functional outcomes of genitoplasty in patients with ambiguous external genitalia due to virilizing congenital adrenal hyperplasia.

\section{PATIENTS AND METHODS}

We studied 34 patients with ambiguous external genitalia due to virilizing congenital adrenal hyperplasia; 33 had 21-hydroxylase deficiency, and 1 had 11- $\beta$-hydroxylase deficiency.

The mean age at surgery was 3.35 years; 18 girls underwent surgery between 0 to 2 years of age, 11 girls at 2 to 5 years of age, and 5 after 5 years of age. The followup ranged from 2 to 16 years.

Genital ambiguity was classified according to Prader stage. ${ }^{6}$ The patient with 11- $\beta$-hydroxylase deficiency presented as Prader V, whereas among patients with 21-hy- droxylase deficiency, 5 presented as Prader II, 16 as Prader III, 11 as Prader IV, and 1 as Prader V (Table 1). Clitoral length ranged from 1.9 to $5.0 \mathrm{~cm} ; 28$ patients had a single perineal orifice, and 6 had a double orifice.

Pelvic ultrasound was performed in all patients before surgery to evaluate internal genitalia.

The patients underwent feminizing genitoplasty between 1986 and 2002. All patients were evaluated at the Endocrinology Unit, and $83 \%$ of the surgeries were performed by the same surgeon (FAQS) from the Urology Department.

The surgery consisted of clitoroplasty, urogenital sinus opening, and vulvoplasty. Two different types of urogenital sinus opening were performed: Y-V flap or cut-back incision. The first technique was used in cases with high vaginal insertion, and the second mainly in cases with low insertion.

Opening of the urogenital sinus. An inverted V-shaped incision was made in the perineum. A perineal flap was

Table 1 - Grade of virilization of external genitalia, surgical technique and results of patients undergoing feminizing genitoplasty

\begin{tabular}{|c|c|c|c|c|c|c|c|}
\hline $\mathrm{N}$ & Prader & $\begin{array}{l}\text { Urogenital } \\
\text { Sinus }\end{array}$ & $\begin{array}{l}\text { Clitoris size } \\
\quad(\mathrm{cm})\end{array}$ & Technique & Complications & VaginalDilation & Intercourse \\
\hline 1 & III & Yes & 3.3 & $\mathrm{Y}-\mathrm{V}$ & No & No & No \\
\hline 2 & $\mathrm{~V}$ & Yes & 2.1 & cut-back & No & No & No \\
\hline 3 & III & Yes & 2.0 & clitoroplasty & clitoromegaly & No & No \\
\hline 4 & III & Yes & 2.1 & Y-V & vaginal stenosis & Yes & No \\
\hline 5 & IV & Yes & 2.0 & Y-V & urinary Infection & No & No \\
\hline 6 & IV & Yes & 3.3 & Y-V & clitoromegaly & No & No \\
\hline 7 & IV & Yes & 2.5 & Y-V & bleeding/stenosis & No & No \\
\hline 8 & IV & Yes & 2.0 & cut-back & No & No & No \\
\hline 9 & III & Yes & 1.9 & cut-back & $\begin{array}{l}\text { stenosis / urinary infection } \\
\text { (Reflux) }\end{array}$ & No & No \\
\hline 10 & IV & Yes & 2.5 & Y-V & stenosis & No & No \\
\hline 11 & IV & Yes & 2.5 & Y-V & No & No & No \\
\hline 12 & III & Yes & 2.7 & Y-V & No & No & No \\
\hline 13 & III & Yes & 5.0 & Y-V & No & No & No \\
\hline 14 & IV & Yes & 2.7 & Y-V & No & No & No \\
\hline 15 & II & No & 4.5 & cut-back & No & No & No \\
\hline 16 & II & No & 2.5 & cut-back & No & No & No \\
\hline 17 & III & Yes & 2.0 & $\mathrm{Y}-\mathrm{V}$ & No & No & No \\
\hline 18 & III & Yes & 2.0 & cut-back & No & No & No \\
\hline 19 & II & No & 2.7 & $\mathrm{Y}-\mathrm{V}$ & No & No & No \\
\hline 20 & III & Yes & 2.0 & cut-back & No & No & No \\
\hline 21 & II & No & 4.5 & $\mathrm{Y}-\mathrm{V}$ & No & No & No \\
\hline 22 & III & No & 5.0 & Y-V & No & No & Yes \\
\hline 23 & III & Yes & 1.9 & $\mathrm{Y}-\mathrm{V}$ & No & No & No \\
\hline 24 & III & Yes & 2.5 & cut-back & intercourse with pain & Yes & Yes \\
\hline 25 & II & No & 5.0 & $\mathrm{Y}-\mathrm{V}$ & No & No & No \\
\hline 26 & IV & Yes & 2.0 & $\mathrm{Y}-\mathrm{V}$ & No & No & No \\
\hline 27 & III & Yes & 1.9 & $\mathrm{Y}-\mathrm{V}$ & stenosis & Yes & No \\
\hline 28 & V & Yes & 2.9 & Y-V & No & No & No \\
\hline 29 & III & Yes & 2.0 & Y-V & No & No & Yes \\
\hline 30 & IV & Yes & 2.5 & Y-V & bleeding & No & No \\
\hline 31 & IV & Yes & 2.5 & Y-V & No & No & No \\
\hline 32 & III & Yes & 2.2 & Y-V & No & No & No \\
\hline 33 & IV & Yes & 5.0 & Y-V & No & No & No \\
\hline 34 & III & Yes & 1.9 & Y-V & No & No & No \\
\hline
\end{tabular}


developed, taking care to avoid injury to the underlying rectum. The urogenital sinus was then divided along its posterior wall well up into the vagina. It was necessary to extend the incision 1 to $2 \mathrm{~cm}$ into the vagina to interpose enough of the perineal flap into the vaginal introitus (Y-V plasty) to produce adequate enlargement.

Clitoroplasty. Clitoroplasty was carried out through a semi-circumferential incision at the base of the glans; the proximal ends of each corporeal body were exposed and suture-ligated at the crura. The corporeal bodies were excised with preservation of the glans attached to the ventral mucosa. Seven patients also had dorsal nerves and vessels preserved.

Vulvoplasty. The creation of a vulva with normal appearance was achieved by fashioning labia minora from the phallic skin and foreskin, and performing labio-scrotal reduction through bilateral elliptical incisions.

Six months after surgery, the patients were examined in the static position (patient's thighs joined) and in dynamic inspection (gynecological position). Cosmetic results were classified as excellent, good, regular, and bad as follows: excellent, when the clitoral glans and 2 orifices were observed in the perineum; good, when the glans was not observed, but 2 orifices were found; regular, when the glans was present with a single perineal orifice, indicating the persistence of the urogenital sinus; and bad, when the ambiguous genitalia was maintained.

Functional results were evaluated only in pubertal patients, considering vaginal introitus, menstrual flow, and sexual activity with intravaginal coitus. The results were also classified as excellent, good, regular, or bad, as follows: excellent, when the patient had normal menstrual flow and normal vaginal introitus with the possibility of sexual intercourse; good, when the patient had normal menstrual flow, with vaginal introitus stenosis adequately treated by vaginal dilations with acrylic molds; regular, when the patient had normal menstrual flow, vaginal introitus stenosis treated by vaginal dilation, but with persistence of pain or bleeding during intercourse; bad, when the patient did not have normal menstrual flow and could not have intercourse.

Vaginal dilation with acrylic molds was carried out for patients with vaginal stenosis when the wish to initiate sexual intercourse was expressed by the patient.

\section{RESULTS}

Prior to the operative procedure, all patients had a pelvic ultrasound examination disclosing normal female ductal structures and ovaries. The urogenital sinus was present in 28 of the 34 patients, and the remaining 6 had a double orifice (urethral and vaginal).
The Y-V plasty to open the urogenital sinus was performed in 21 patients having a urogenital sinus and in 4 patients having a double perineal orifice; among the 21 patients having a urogenital sinus, a double orifice was identified in 14 patients (67\%) after surgery. The cut-back incision was performed in 8 patients, with 6 of them having a low urogenital sinus and 2 having a double orifice. Three $(50 \%)$ of the 6 patients having a low urogenital sinus presented a double orifice after surgery (Table 1). One patient underwent only clitoroplasty because, at the time of the surgery, the technique used was performed in 2 stages, and vaginoplasty was deferred until adult life.

Clitoroplasty was performed by excision of the corporeal bodies with preservation of the ventral mucosa to maintain the blood supply to the glans in 27 patients; after surgery, 21 of these patients had visible glans, 4 had palpable glans, while in 2 cases the glans could not be found. The remaining 7 patients underwent clitoroplasty with preservation of the dorsal nerves and vessels and ventral mucosa to maintain glans supply; all of these patients had visible glans after surgery.

In the early follow-up, 2 patients had bleeding in the perineal incision that stopped after compression, and 1 patient who presented as Prader stage $\mathrm{V}$ had glans necrosis. In the late follow-up, all patients reported glans sensitivity, although a sensitivity test was not performed.

Eleven patients presented persistence of the urogenital sinus (Table 1), and 1 of them had occasional urinary tract infections. Two patients presented recurrent clitoral hypertrophy after surgery due to poor hyperandrogenism control. The cosmetic results were considered excellent in 18 (53\%) patients (Figure 1), good in 5 (15\%) (Figure 2), and regular in $11(32 \%)$ (Figure 3).

Functional results were evaluated in 12 patients who had entered puberty; none of them presented menstrual flow obstruction. Four patients had vaginal introitus stenosis; 3 of them underwent vaginal dilation with acrylic molds; 1 of these started having sexual intercourse with no pain or bleeding. One of the 4 patients required a repeated Y-V surgical procedure to correct a severe vaginal stenosis. Functional results were considered excellent in 8 (67\%), good in $3(25 \%)$, and regular in $1(8 \%)$ patient.

\section{DISCUSSION}

Surgical management of intersex states involves efforts to achieve near-normal cosmetic and functional results. One of the most common causes of genital ambiguity in females is virilizing congenital adrenal hyperplasia. Feminizing genitoplasty should provide an adequate vaginal opening into the perineum, create a normal-looking vaginal introi- 

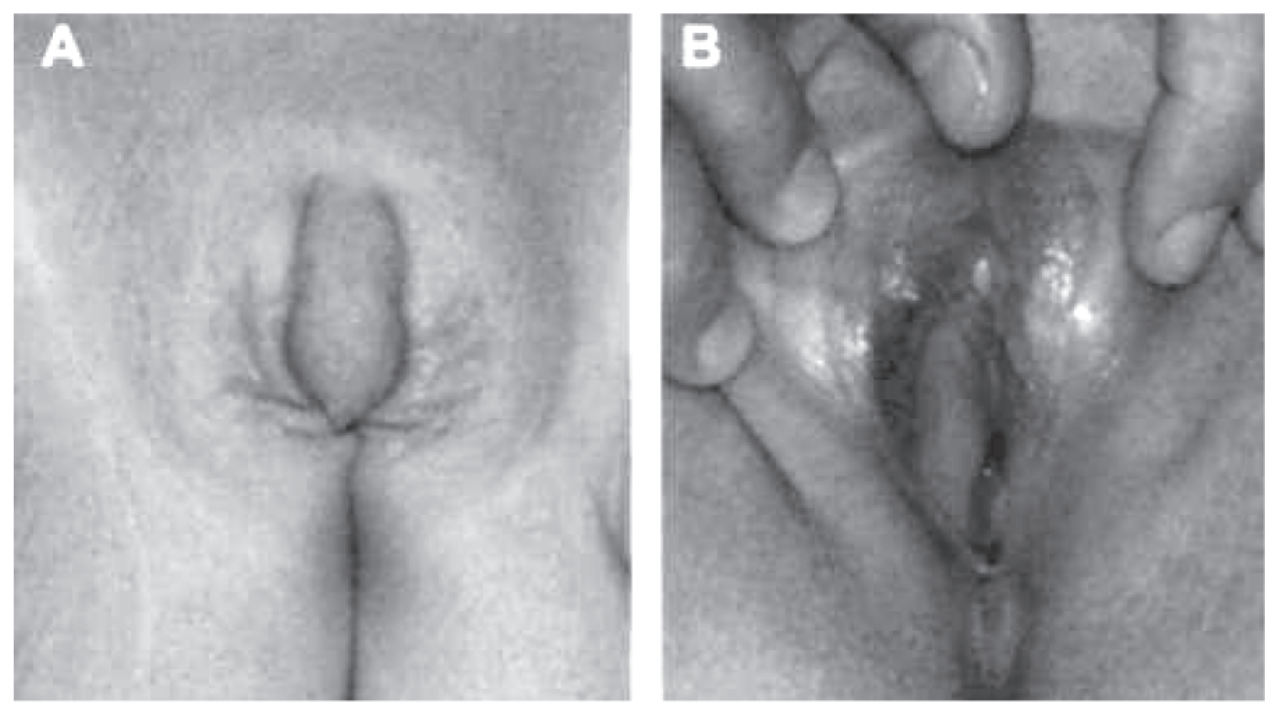

Figure 1 - External genitalia of patient with congenital adrenal hyperplasia before (A) and after (B) genitoplasty - cosmetic result classified as excellent
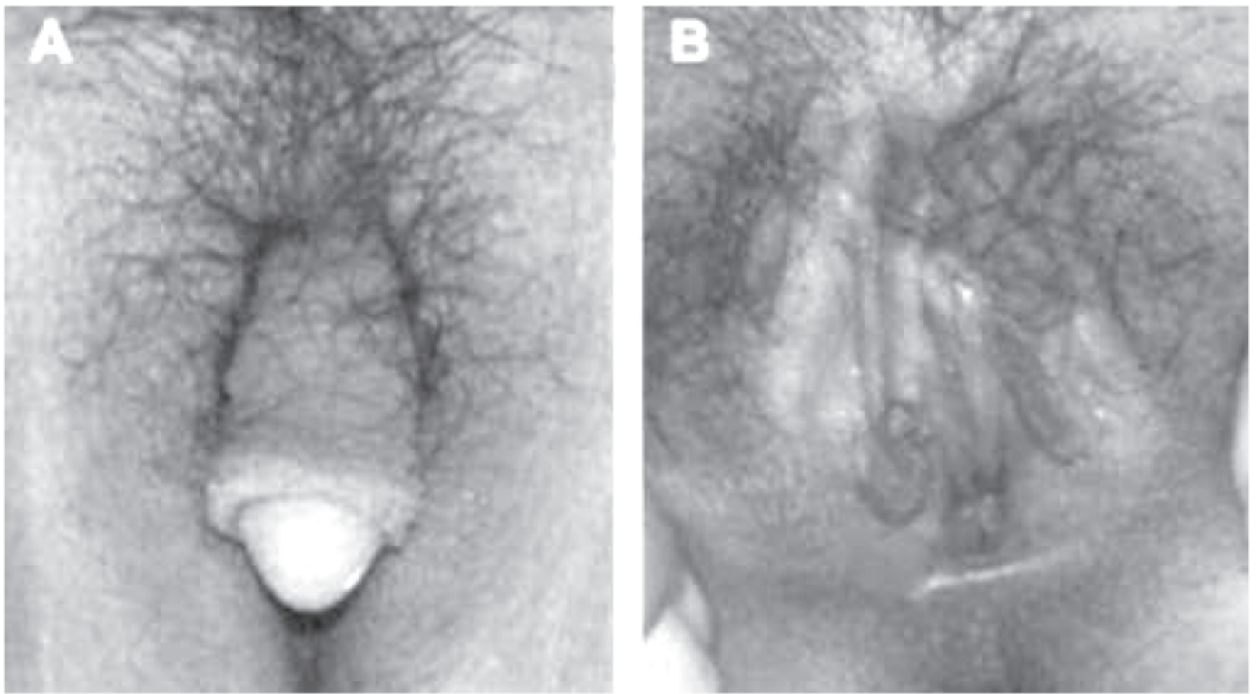

Figure 2 - External genitalia of patient with congenital adrenal hyperplasia before (A) and after (B) genitoplasty - cosmetic result classified as good
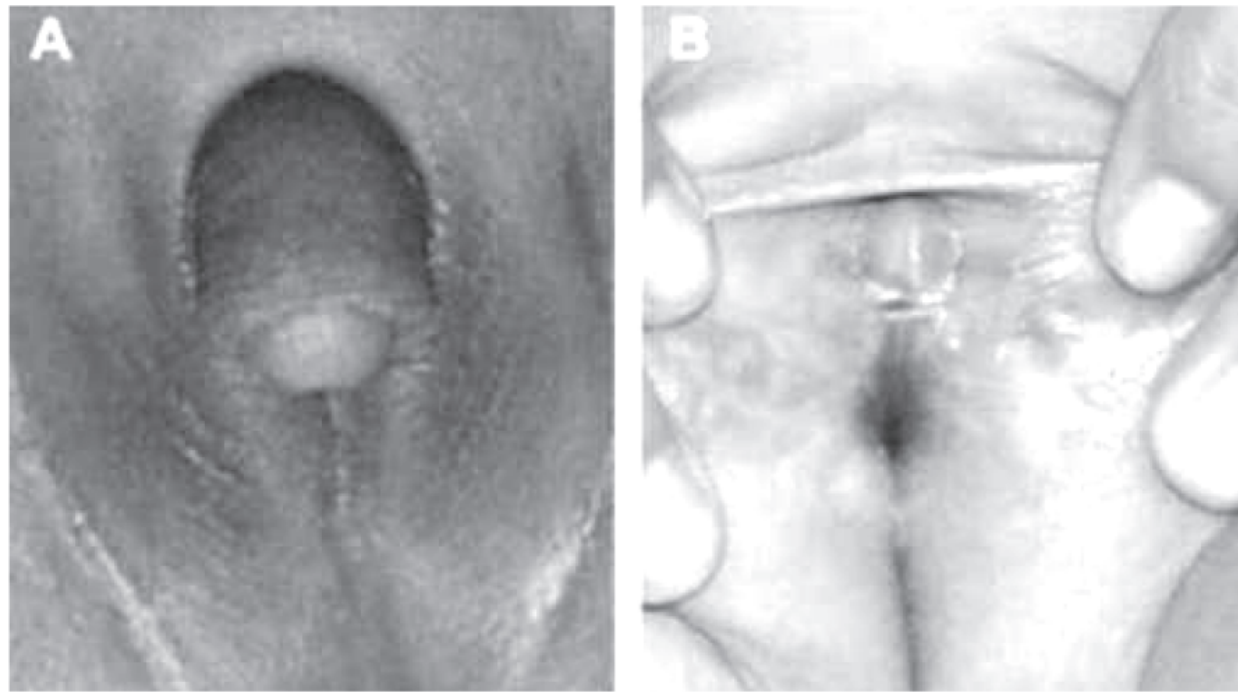

Figure 3 - External genitalia of patient with congenital adrenal hyperplasia before (A) and after (B) genitoplasty - cosmetic result classified as regular 
tus, fully separate the urethral from the vaginal orifice, remove phallic erectile tissue while preserving glandular enervation and blood supply, and preventing urinary tract complications. $^{7}$

Several surgical techniques are available for the reconstruction of external genitalia. ${ }^{7}$ However, the late outcome of feminizing genitoplasty has not been systematically documented in the literature. One enduring controversial point is the optimal time for undergoing genitoplasty. Considering that children have gender notions before 2 years of age, ${ }^{8}$ it is preferable to perform the genitoplasty up until 2 years of age. In our study, 18 patients underwent surgery before 2 years old with good results. This early surgical repair was very important for patients and their families. The patients who underwent genitoplasty at a later age suffered psychological disturbances and did not have better cosmetic or functional results compared with patients undergoing surgery at an early age. These data are in agreement with other studies in which early surgery was recommended. ${ }^{9}$

Historically, clitoral reconstruction has progressed through stages of clitorectomy, followed by clitoral recession, and now, most commonly, clitoral reduction. Clitorectomy results in the obvious loss of sensation and may jeopardize the ability of an orgasmic response to tactile sensation. Clitoral recession maintains sensation; however, pain secondary to clitoral engorgement at the time of sexual arousal can occur. The most reasonable procedure for performing clitoroplasty is based on the concept of maintaining the clitoral glans and sensory input, which facilitates orgasm. ${ }^{10-12}$ The technique consists of the resection of the corpora at the crura with careful preservation of dorsal nerves and vessels and ventral mucosa that supply the glans. However, in the present study, 27 of 34 patients had blood glans supply maintained from the ventral mucosa without preservation of dorsal nerves and vessels, but 2 of them lost the glans. In the remaining 7 cases, both dorsal nerves and vessels and the ventral mucosa were preserved, and none lost the clitoris, suggesting that this technique is safer for preserving the glans.

The next step in feminizing genitoplasty is the opening of the urogenital sinus and vaginoplasty. There are several surgical techniques for performing vaginoplasty, which are in part, chosen according to the position of the vaginal insertion. ${ }^{13-15}$ In some cases, the vagina lies just beneath the perineum (low vaginal insertion) and can be exteriorized by a simple cut-back incision. ${ }^{16}$ In the present study, 8 patients underwent the cut-back procedure. However, in patients with stages III to IV of Prader classification, in whom the vagina presents a high insertion, other procedures are used, such as pull-through vaginoplasty, ${ }^{5}$ construction of a neovagina using an intestinal loop, ${ }^{17}$ and skin flaps from foreskin to construct the lower vaginal portion. ${ }^{14}$ These procedures have been associated with several complications, the most common one being vaginal stenosis. ${ }^{18}$ In the present study, we chose the $\mathrm{Y}-\mathrm{V}$ plasty technique to open the urogenital sinus, with good results even in cases with high vaginal insertion. When the vaginal introitus could not be reached, the urogenital sinus was surgically enlarged using the $\mathrm{Y}-\mathrm{V}$ plasty technique. The absence of a separate vaginal opening does not impair sexual intercourse or cause urinary tract infections. The high vagina usually drains well via a urogenital sinus and rarely pools sufficient urine to be a source of infection or interfere with normal bladder emptying. In this study, only 1 patient with persistence of a urogenital sinus had occasional urinary tract infections. ${ }^{19}$

To avoid introital stenosis in $\mathrm{Y}-\mathrm{V}$ vaginoplasty, the use of an adequately sized tissue flap is mandatory. Failure to interpose an adequate flap will result in persistent introital stenosis, requiring later revision. ${ }^{19}$ In our study, 1 patient who developed introitus stenosis required a surgical correction. Vaginal dilation with acrylic molds in patients with introitus stenosis was a good treatment choice when these patients wished to start sexual intercourse, resulting in good outcomes. ${ }^{20}$

Good morphological and functional results were achieved in $68 \%$ of the patients, which is a better outcome in comparison with another series in which patients underwent neovaginoplasty, and for which a second surgery was required to correct vaginal stenosis in $93 \%$ of the cases. ${ }^{3}$

We conclude that single-stage feminizing genitoplasty consisting of clitoroplasty with the preservation of dorsal nerves and vessels and ventral mucosa, vulvoplasty, and use of a Y-V perineal flap, followed by vaginal dilation with acrylic molds, produced good cosmetic and functional results in virilized girls with congenital adrenal hyperplasia, avoiding the need to create a neovagina even in patients with high vaginal insertion.

\section{RESUMO}

Sircili MHP, Mendonça BB de, Denes FT, Madureira G, Bachega TASS, Queiroz e Silva FA de. Existem muitas controvérsias quanto à melhor técnica e a idade ideal para a realização da genitoplastia feminizante e poucos trabalhos relatam seus resultados em longo prazo. Clinics. 2006;61(3):209-14.

OBJETIVO: Apresentar um estudo retrospectivo sobre os 
resultados cosméticos e funcionais da genitoplastia feminizante em pacientes com hiperplasia adrenal congênita virilizante.

MÉTODOS: Trinta e quatro pacientes com idade média de 3,35 $\pm 2,5$ anos com ambigüidade genital classificada de acordo com os estádios de Prader foram selecionados. O seguimento pós-operatório foi de 2 a 16 anos. O tamanho do clitóris variou de 1,9 a $5,0 \mathrm{~cm} ; 28$ pacientes tinham orifício único perineal e 6 tinham dois orifícios. A técnica cirúrgica incluiu clitorovaginoplastia em tempo único e foi realizada antes dos dois anos de idade em 18 pacientes. A clitoroplastia preservou a glande, a qual teve seu suprimento sanguíneo mantido em $97 \%$ dos casos pela mucosa do freio e no demais casos com a manutenção do feixe vasculo-nervoso dorsal. Duas técnicas foram utilizadas para a ampliação do seio urogenital: o retalho perineal em "Y-
V" em 25 pacientes e a incisão longitudinal posterior em 8 pacientes.

RESULTADOS: As complicações cirúrgicas ocorreram em 20,5\% dos casos: sangramento, necrose da glande e estenose vaginal. Foram necessárias dilatações vaginais com moldes de acrílico no período pós puberal em 3 das pacientes com estenose, com bons resultados funcionais.

CONCLUSÃO: As técnicas utilizadas seguidas pelas dilatações, permitiram bons resultados cosméticos e funcionais em $67 \%$ dos casos apresentando poucas complicações e evitando a necessidade de neovagina inclusive nos pacientes com inserção alta do intróito vaginal.

UNITERMOS: Genitália ambígua. Hiperplasia adrenal congênita. Genitoplastia feminizante. Resultados cosméticos e funcionais.

\section{REFERENCES}

1. Hendren WH, Crawford JD. The child with ambiguous genitália. A series of monthly clinical monographs. Year Book Medical Publisher. Chicago; 1972. p. 64.

2. Kowarski A, Finkelstein JW, Spaulding JS, Hohman GH, Migeon CJ. Aldosterone secretion rate in congenital adrenal hyperplasia: a discussion of theories on the pathogenesis of the salt-losing form of the syndrome. J Clin Invest. 1965;44:505-13.

3. Alizai NK, Thomas DF, Lilford RJ, Batchelor AG, Johnson N. Feminizing genitoplasty for congenital adrenal hyperplasia: what happens at puberty? J Urol. 1999;61:588-91.

4. Farkas A, Chertin B, Hadas-Halpren I. 1 Stage feminizing genitoplasty: 8 years of experience with 49 cases. J Urol. 2001;165:341-6.

5. Hendren WH, Atala A. Repair of the high vagina in girls with severe masculinized anatomy from adrenogenital syndrome. J Pediatr Surg. 1995;30:91-4.

6. Prader A. Der genitalbefund beim pseudohermaphroditismus femininus des krongenitalen adrenogenitalen syndromes: morphologia, häufigkeit, entwicklung and vererbung der verschiedenen genitalformen. Helv Paediat Acta. 1954;9:231-48.

7. Rink RC, Adams MC. Feminizing genitoplasty: state of the art. World J Urol. 1998;16:212-8.

8. Hecker WC. Operative correction of intersexual genitals in children. Prog Pediatr Surg. 1984;17:21-31.

9. Money J, Hampson JG, Hampson JL. Hermaphroditism: Recommendations concerning assignment of sex, change of sex and psychological management. Bull of Johns Hopkins Hospital. 1955;97:284

10. Allen LE, Hardy BE, Churchill BM. The surgical management of the enlarged clitoris. J Urol. 1982;128:351-4.
11. Spence HM, Allen TD. Genital reconstruction in female with the adrenogenital syndrome. Br J Urol. 1973;45:26-30.

12. Gearhart JP, Burnett A, Owen JH. Measurement of pudental evoked potentials during feminizing genitoplasty: Techniques and applications. J Urol. 1995;153:486.

13. Hendren WH, Donahoe PK. Correction of congenital abnormalities of the vagina and perineum. J Pediatr Surg. 1980;15:751-63.

14. Passerini-Glazel G. A new 1-stage procedure for clitorovaginoplasty in severely masculinized female pseudohermaphrodites. J Urol. 1989;142:565-8.

15. Parrott TS, Woodard JR. Abdominoperitoneal approach to management of the high, short vagina in the adrenogenital syndrome. J Urol. 1991;146:647-8.

16. Hendren WH, Crawford JD. Adrenogenital syndrome: Anatomy of the anomaly and its repair. Some new concepts. J Pediatr Surg. 1969;4:4958.

17. Freitas Filho LG, Carnevale J, Melo CE, Larks M, Miranda EG. Sigmoid reconfigured vaginal construction in children. J Urol. 2001;166:426-8.

18. Lobe TE, Woodall DL, Richards AC, Meyer WJ. The complications of surgery for intersex: changing patters over two decades. J Pediatr Surg. 1987;22:651-2.

19. Snyder $3^{\text {RD }}$ HM, Retik AB, Bauer SB, Colodny AH. Feminizing genitoplasty: a synthesis. J Urol. 1983;129:1024-6.

20. Costa EM, Mendonca BB, Inácio M, Arnhold IJP, Silva FA, Lodovici O. Management of ambiguous genitalia in pseudohermaphrodites: new perspectives on vaginal dilation. Fertil Steril. 1997;67:229-32. 